\title{
Variation in xylem characteristics of botanical races of Persea americana and their potential influence on susceptibility to the pathogen Raffaelea lauricola
}

\author{
G. L. Beier ${ }^{1}$ - C. D. Lund ${ }^{2}$ B. W. Held ${ }^{2} \cdot$ R. C. Ploetz ${ }^{3} \cdot$ J. L. Konkol ${ }^{3} \cdot$ R. A. Blanchette ${ }^{2}$ (I) \\ Received: 10 June 2020 / Accepted: 21 August 2020 / Published online: 18 September 2020 \\ (C) The Author(s) 2020
}

\begin{abstract}
Avocado (Persea americana), an important fruit crop, is under threat from an invasive disease, laurel wilt. The pathogen, Raffaelea lauricola, spreads rapidly in the xylem of infected trees and causes a lethal vascular wilt. A previous study showed that variation in susceptibility to the disease exists among different races of avocado, with the West Indian race being most susceptible. To help elucidate potential explanations for differences in susceptibility, xylem characteristics were examined for fourteen avocado cultivars from the Guatemalan, Mexican, and West Indian botanical races. Samples of each cultivar were assessed for vessel size, vessel density, vessel aggregation, and xylem-specific potential hydraulic conductivity. The West Indian race had significantly greater mean vessel diameters, mean maximum vessel diameters, and xylem-specific potential hydraulic conductivities than the Guatemalan and Mexican races $(p<0.05)$, which in turn did not differ for any of these variables $(p>0.05)$. There were no significant differences among the races for vessel aggregation or vessel density. Cultivars of the Mexican and Guatemalan races generally had smaller mean vessel diameters, mean maximum vessel diameters, and mean xylem-specific potential hydraulic conductivities than the West Indian race; however, there was considerable variation among cultivars of the Mexican race. Statistically significant differences in vessel grouping indices and vessel solitary fractions were evident among some cultivars but to lesser extents than were found for vessel size. This study indicates that larger vessel diameters and greater potential hydraulic conductivities exist in the West Indian, compared with the Guatemalan and Mexican races. We suggest that these attributes may be contributing factors in the greater susceptibility to laurel wilt that is evident in the West Indian race.
\end{abstract}

Keywords Hydraulic conductivity $\cdot$ Lauraceae $\cdot$ Laurel wilt $\cdot$ Wood anatomy $\cdot$ Xylem vessel diameter

\section{Introduction}

Laurel wilt is a lethal disease of plants in the Lauraceae family that is caused by an ambrosia beetle symbiont,

Electronic supplementary material The online version of this article (https://doi.org/10.1007/s40858-020-00397-y) contains supplementary material, which is available to authorized users.

G. L. Beier

gbeier@mchenry.edu

1 McHenry County College, 8900 US Hwy 14, Crystal Lake, IL 60012, USA

2 Department of Plant Pathology, University of Minnesota, St. Paul, MN 55108, USA

3 Department of Plant Pathology, Tropical Research \& Education Center, University of Florida, Homestead, FL 33031, USA
Raffaelea lauricola T.C. Harr., Fraedrich \& Aghayeva (Harrington et al. 2008). The disease has caused significant damage to native ecosystems in the southeastern United States (Fraedrich et al. 2008) and threatens the global production of a valuable food crop, avocado (Persea americana Mill.) (Ploetz et al., 2017). In the USA, there were 56,580 acres of avocado in production during the 2017-2018 season, with an estimated value of approximately 390 million dollars (National Agricultural Statistics Service 2018). Additionally, the USA imported avocados from Mexico in 2018 worth more than 2 billion dollars (Economic Research Service 2019).

Avocado is divided into three botanical races, Mexican (var. drymifolia [Schltdl. et Cham.] S. F. Blake), Guatemalan (var. guatemalensis L. O. Wms.), and West Indian (var. americana Mill.), which vary in several commercial and cultural traits (Chanderbali et al. 2013). While some commercial cultivars neatly fall into one of these races, others 
are racial hybrids (Schnell et al. 2003; Chen et al. 2009). Cultivars do not show uniform susceptibility to laurel wilt; for example, a study by Ploetz et al. (2012) demonstrated that West Indian cultivars were generally more susceptible to laurel wilt than Guatemalan cultivars or Guatemalan $\times$ Mexican hybrids. Additionally, avocado samples received for laurel wilt diagnoses by the University of Florida clinic in Homestead were most frequently of the West Indian race (unpublished data).

While it has been shown that the West Indian race generally shows greater susceptibility to laurel wilt than genotypes with a Mexican or Guatemalan background (Ploetz et al. 2012), it is still unclear what mechanisms or characteristics make the West Indian race more susceptible. Having a greater understanding of resistance mechanisms would allow breeders to more efficiently cross and select for resistance to laurel wilt. One potential explanation for the variation in resistance to laurel wilt is differences in anatomical features. Xylem characteristics that are associated with water transport have been correlated with increased susceptibility in other woody plant diseases that are similar to laurel wilt (Elgersma 1970; McNabb Jr et al., 1970; Sinclair et al. 1975; Solla and Gil 2002; Pouzoulet et al. 2014; Pouzoulet et al. 2017). For example, in the highly studied Dutch elm disease pathosystem, susceptible genotypes of Ulmus generally have larger vessel diameters than those that are resistant (Elgersma 1970; McNabb Jr et al., 1970; Sinclair et al. 1975; Solla and Gil 2002). Additionally, studies in Vitis have found that larger vessel diameters are associated with greater susceptibility to Esca, which is a vascular wilt disease (Pouzoulet et al. 2014; Pouzoulet et al. 2017). Recently, Ploetz et al. (2015) reported significantly greater sap flow rates in a West Indian avocado cultivar highly susceptible to laurel wilt, compared with two less susceptible cultivars; they hypothesized that "susceptibility to laurel wilt is related to its ability to conduct water."

A preliminary study reported that trees of the West Indian race appeared to have significantly larger mean vessel diameters than those of the Guatemalan or Mexican races (ReyesSantamaría et al., 2002). In their study, representatives of the different races used were wild types rather than cultivars. In the study we present here, three, five, and six cultivars of the Guatemalan, Mexican, and West Indian races, respectively, were examined for vessel size, density, aggregation, and xylem-specific potential hydraulic conductivity. A study by Ploetz et al. (2012) assessed six of the cultivars used in this study for their susceptibility to laurel wilt, including "Bacon," "Catalina," "Donnie," "Pollock," "Simmonds," and "Waldin." Other botanical races that were evaluated in our study were grown in California, and inoculations with the $R$. lauricola have not been conducted since the pathogen is not found in California. However, it was important to include these races to evaluate their xylary characteristics and compare them to those that have been tested for susceptibility to the pathogen. Our working hypothesis was that cultivars of the West Indian race would differ in xylem characteristics compared with other races.

\section{Materials and methods}

\section{Plant material}

Based on availability, one to three trees of each of the 14 Persea americana cultivars were sampled (Table 1). Cultivar confirmation was previously determined using microsatellite markers (Ashworth and Clegg 2003; Boza et al. 2018; Schnell et al., 2003), SNP's (Kuhn et al. 2019), or morphological methods and is noted in Table 1.

Each tree was considered an experimental unit. With the exception of two of the three "Nabal" samples and all of the "Duke" samples, which were from Irvine, California, all other samples were from southeastern Florida. At the time of harvest, trees ranged in age from 15 to 35 years old.

\section{Sample collection}

Plant material was collected from June 2016 through June 2017. From each tree, one large branch approximately $5-10 \mathrm{~cm}$ in diameter was cut transversely using a chainsaw and subsequently cut using a band saw to a length of approximately $9 \mathrm{~cm}$. Other than the $9-\mathrm{cm}$ segment, all the remaining pieces of the branch were discarded. The cut pieces were then wrapped with moist paper towels and shipped to St. Paul, Minnesota, for processing. Samples were then cut transversely again using a band saw so that the sample was approximately $1 \mathrm{~cm}$ thick. These samples were stored at $-20{ }^{\circ} \mathrm{C}$ until sectioned.

\section{Histology}

For each stem sample, four free-hand transverse sections, approximately $40 \mu \mathrm{m}$ thick, were made. Sections were approximately $0.5 \mathrm{~cm}$ wide by $3 \mathrm{~cm}$ long, starting at the vascular cambium and moving inward toward the pith. The sections were spaced $90^{\circ}$ apart with a random starting point. Immediately following sectioning, sections were stained for $20 \mathrm{~s}$ with a $0.1 \%$ safranin $\mathrm{O}$ (dye content $\geq 85 \%$ ) (SigmaAldrich ${ }^{\circledR}$, St. Louis, MO) (w/v) solution, excess safranin O was removed by absorbing it with a paper towel, and a wet mount was made. The wet mount was made by placing a drop of DI water onto the surface of the sample and then subsequently covering the sample with a cover slip. Sections were allowed to air dry at room conditions before they were photographed. Images were taken at $\times 40$ using a Nikon DSRi1 (Nikon Instruments Inc., Melville, NY) mounted on a Nikon Eclipse Ni-U microscope (Nikon Instruments Inc., 
Table 1 Botanical races of Persea americana cultivars used in the study

\begin{tabular}{|c|c|c|c|c|}
\hline Race & Cultivar & $n^{\mathrm{y}}$ & Location $^{\mathrm{z}}$ & Confirmation \\
\hline \multirow[t]{3}{*}{ Guatemalan } & Nabal & 3 & $\begin{array}{l}\text { USDA-ARS Miami and } \\
\text { UC-SCREC }\end{array}$ & $\begin{array}{l}\text { Molecular (Ashworth and Clegg 2003; } \\
\text { Schnell et al., 2003) }\end{array}$ \\
\hline & R14T01 & 3 & USDA-ARS Miami & Molecular (Kuhn et al. 2019) \\
\hline & R14T06 & 2 & USDA-ARS Miami & Molecular (Kuhn et al. 2019) \\
\hline \multirow[t]{5}{*}{ Mexican } & Bacon & 3 & USDA-ARS Miami & Molecular (Schnell et al., 2003) \\
\hline & Duke & 3 & UCR & Molecular (Kuhn et al. 2019) \\
\hline & Egas & 1 & USDA-ARS Miami & Molecular (Schnell et al., 2003) \\
\hline & LaPiscina & 1 & USDA-ARS Miami & MoSchnell et al., 2003lecular () \\
\hline & Romain & 2 & USDA-ARS Miami & Molecular (Schnell et al., 2003) \\
\hline \multirow[t]{6}{*}{ West Indian } & Catalina & 3 & $\begin{array}{l}\text { USDA-ARS Miami and } \\
\text { Fairchild Farm }\end{array}$ & $\begin{array}{l}\text { Molecular (Schnell et al., 2003; Boza et al. } \\
\text { 2018) }\end{array}$ \\
\hline & Dade & 2 & USDA-ARS Miami & Molecular (Schnell et al., 2003) \\
\hline & Donnie & 3 & UF-TREC & Morphological \\
\hline & Pollock & 1 & USDA-ARS Miami & Molecular (Schnell et al., 2003) \\
\hline & Simmonds & 3 & UF-TREC & Morphological \\
\hline & Waldin & 3 & $\begin{array}{l}\text { USDA-ARS Miami and } \\
\text { Fairchild Farm }\end{array}$ & $\begin{array}{l}\text { Molecular (Schnell et al., 2003; Boza et al. } \\
\text { 2018) }\end{array}$ \\
\hline
\end{tabular}

${ }^{\mathrm{y}} n$ represents the number of trees sampled

${ }^{\mathrm{z}}$ Sample collection location abbreviations: Fairchild Farm, Fairchild Tropical Botanical Garden, Fairchild Farm Genetic Facility, 14,885 SW 248 Street, Homestead, FL 33032; UCR, University of California Riverside, Department of Agricultural Operations, Avocado Germplasm Collection, 1060 Martin Luther King Boulevard, Riverside, CA 92506; UC-SCREC, University of California South Coast Research and Extension Center, Avocado Germplasm Collection, 7601 Irvine Boulevard, Irvine, CA 92618; UF-TREC, University of Florida Tropical Research and Education Center, Avocado Germplasm Collection, 18,905 SW 280 Street, Homestead, FL 33031; USDA-ARS Miami, USDA-ARS, SHRS, NCGR, National Germplasm Repository, 13,601 Old Cutler Road, Miami, FL 33158
Melville, NY). Due to the large size of the area of xylem being assessed, multiple images of the same section were taken and merged using the scan large image feature in Nikon Elements Advanced Research (Nikon Instruments Inc., Melville, NY). To ensure that the entire image was in focus, Z-stacking was performed as necessary using Nikon Elements Advanced Research.

\section{Xylem analysis}

Within stem sections, $4 \mathrm{~mm} \times 1 \mathrm{~mm}$ areas of the xylem were analyzed, starting $3.2 \mathrm{~mm}$ proximal from the vascular cambium. All complete vessel elements within the cropped area were manually traced or selected using the magic wand in Photoshop $^{\text {TM }}$ (Adobe Systems Inc., San Jose, CA) and analyzed using the thresholding feature in ImageJ (Schneider et al. 2012). A black mask was then generated to include vessel elements with circle diameters, $D, \geq 20 \mu \mathrm{m}$; masked images generated in ImageJ were then analyzed using ROXAS 3.0 (von Arx et al., 2013). For grouped vessel elements, a double cell wall thickness was set at $10 \mu \mathrm{m}$ to ensure that most grouped vessels were included. Vessel diameter $(D)$ and maximum vessel diameter $\left(D_{\mathrm{MAX}}\right)$ were the diameters of circles in $\mu \mathrm{m}$ with the same area as the measured vessel. Vessel density $\left(V_{\mathrm{D}}\right)$ was vessels $/ \mathrm{mm}^{2}$, and vessel grouping index $\left(V_{\mathrm{G}}\right)$ was the mean number of vessels per group, where solitary vessels were considered a group (Carlquist 2001). Finally, vessel solitary fraction $\left(V_{S}\right)$ was the ratio of solitary vessels over all vessels, and mean group size $\left(V_{\mathrm{M}}\right)$ was the mean size of groups of nonsolitary vessels (von Arx et al. 2013). Xylem-specific potential hydraulic conductivity (Ks) in $\mathrm{kg} \mathrm{m}^{-2} \mathrm{MPa}^{-1} \mathrm{~s}^{-1}$ was calculated using ROXAS 3.0 (von Arx et al. 2013) by dividing the accumulated potential hydraulic conductivity $\left(\mathrm{kg} \mathrm{MPa}^{-1} \mathrm{~s}^{-1}\right)$, which was approximated by Poiseuille's law and adjusted to elliptical tubes (Nonweiler 1975), by the xylem area examined.

\section{Statistical analysis}

Statistical analyses were performed with $\mathrm{R}$ version 3.2.2 ( $\mathrm{R}$ Development Core Team, Vienna, Austria). When performing statistical analysis on the different races, all cultivars were included regardless of the number of replicates (Table 2). When comparing individual cultivars, only cultivars with 3 or more replicates were included in the analysis; however, all the means are shown (Tables 3 and 4). Data for the different 
Table 2 Summary of xylem characteristics of Persea americana according to race

\begin{tabular}{llll}
\hline Variable $^{\mathrm{x}, \mathrm{y}, \mathrm{z}}$ & \multicolumn{3}{l}{ Race } \\
\cline { 2 - 4 } & \multicolumn{2}{l}{ Mean $\pm \mathrm{SE}$} & \\
\cline { 2 - 4 } & Guatemalan $(n=8)$ & Mexican $(n=10)$ & West Indian $(n=15)$ \\
\hline$D$ & $82.5 \pm 1.7 \mathrm{~b}$ & $84.2 \pm 3.0 \mathrm{~b}$ & $98.6 \pm 2.1 \mathrm{a}$ \\
$D_{\mathrm{MAX}}$ & $132.0 \pm 2.6 \mathrm{~b}$ & $131.5 \pm 4.2 \mathrm{~b}$ & $151.2 \pm 4.0 \mathrm{a}$ \\
$V_{\mathrm{D}}$ & $22.8 \pm 1.7 \mathrm{a}$ & $21.7 \pm 1.6 \mathrm{a}$ & $24.9 \pm 0.9 \mathrm{a}$ \\
$V_{\mathrm{G}}$ & $1.34 \pm 0.04 \mathrm{a}$ & $1.41 \pm 0.07 \mathrm{a}$ & $1.48 \pm 0.03 \mathrm{a}$ \\
$V_{S}$ & $55.05 \pm 3.63 \mathrm{a}$ & $50.20 \pm 4.76 \mathrm{a}$ & $42.99 \pm 2.10 \mathrm{a}$ \\
$V_{\mathrm{M}}$ & $2.19 \pm 0.03 \mathrm{a}$ & $2.22 \pm 0.05 \mathrm{a}$ & $2.27 \pm 0.03 \mathrm{a}$ \\
$\mathrm{Ks}$ & $9.49 \mathrm{E}-07 \pm 6.61 \mathrm{E}-08 \mathrm{~b}$ & $9.62 \mathrm{E}-07 \pm 9.22 \mathrm{E}-08 \mathrm{~b}$ & $1.74 \mathrm{E}-06 \pm 1.05 \mathrm{E}-07 \mathrm{a}$ \\
\hline
\end{tabular}

${ }^{\mathrm{x}}$ Variables are $D$, equivalent circle diameter (diameter of the circle having the same area as the measured vessel in $\mu \mathrm{m}) ; D_{\mathrm{MAX}}$, maximum vessel diameter (diameter of the circle having the same area as the measured vessel in $\mu \mathrm{m}$ ); $V_{D}$, vessel density (number of vessels per $\mathrm{mm}^{2}$ ); $V_{\mathrm{G}}$, vessel grouping index (mean number of vessels per group, solitary vessels are also considered a group); $V_{S}$, vessel solitary fraction (ratio of solitary vessels to all vessels); $V_{\mathrm{M}}$, mean group size of nonsolitary vessels; Ks, xylem-specific potential hydraulic conductivity $\left(\mathrm{kg} \mathrm{m}^{-2} \mathrm{MPa}^{-1} \mathrm{~s}^{-1}\right)$

${ }^{\mathrm{y}}$ Except for the variables $V_{\mathrm{D}}$ and $V_{\mathrm{M}}$, means containing the same letter within a row are not significantly different according to Fisher's LSD multiple comparisons test with a Benjamini and Hochberg $p$ value adjustment $(\alpha=$ $0.05)$

${ }^{\mathrm{z}} V_{\mathrm{D}}$ and $V_{\mathrm{M}}$ were analyzed using nonparametric analysis due to violations of the assumptions of ANOVA. Groups with the same letter in the same row were not statistically significant according to Dunn's multiple comparison with a Benjamini and Hochberg $p$ value adjustment $(\alpha=0.05)$

xylem characteristics were examined for normal distribution and homoscedasticity using the Shapiro-Wilk Normality Test and Levene's Test for homogeneity of variance, respectively. Data that did not violate assumptions of normality were
Table 3 Summary of vessel size and xylem-specific potential hydraulic conductivity of Persea americana cultivars

\begin{tabular}{|c|c|c|c|c|c|c|}
\hline \multicolumn{7}{|c|}{ Variable $(\text { Mean } \pm \mathrm{SE})^{\mathrm{x}, \mathrm{y}, \mathrm{z}}$} \\
\hline Race & Cultivar & $n$ & Source & $D$ & $D_{\text {MAX }}$ & Ks \\
\hline \multirow[t]{3}{*}{ Guatemalan } & Nabal & 3 & FL \& CA & $84.2 \pm 2.1 \mathrm{bc}$ & $128.6 \pm 2.8 \mathrm{de}$ & $8.90 \mathrm{E}-07 \pm 1.71 \mathrm{E}-07 \mathrm{de}$ \\
\hline & R14T01 & 3 & FL & $79.4 \pm 3.0 \mathrm{c}$ & $128.5 \pm 0.7 \mathrm{de}$ & $9.20 \mathrm{E}-07 \pm 4.59 \mathrm{E}-08 \mathrm{de}$ \\
\hline & R14T06 & 2 & FL & $84.7 \pm 4.5$ & $142.4 \pm 4.5$ & $1.08 \mathrm{E}-06 \pm 7.00 \mathrm{E}-08$ \\
\hline \multirow[t]{5}{*}{ Mexican } & Bacon & 3 & FL & $79.0 \pm 2.2 \mathrm{c}$ & $121.9 \pm 1.4 \mathrm{e}$ & $6.67 \mathrm{E}-07 \pm 3.94 \mathrm{E}-08 \mathrm{e}$ \\
\hline & Duke & 3 & $\mathrm{CA}$ & $92.1 \pm 4.9 \mathrm{ab}$ & $142.2 \pm 2.6 \mathrm{bcd}$ & $1.10 \mathrm{E}-06 \pm 1.29 \mathrm{E}-07 \mathrm{cde}$ \\
\hline & Egas & 1 & FL & $74.8 \pm \mathrm{NA}$ & $115.7 \pm \mathrm{NA}$ & $6.60 \mathrm{E}-07 \pm \mathrm{NA}$ \\
\hline & LaPiscina & 1 & FL & $98.7 \pm \mathrm{NA}$ & $155.7 \pm \mathrm{NA}$ & $1.38 \mathrm{E}-06 \pm \mathrm{NA}$ \\
\hline & Romain & 2 & FL & $77.7 \pm 1.2$ & $125.6 \pm 0.5$ & $1.15 \mathrm{E}-06 \pm 6.50 \mathrm{E}-08$ \\
\hline \multirow[t]{6}{*}{ West Indian } & Catalina & 3 & FL & $101.4 \pm 1.2 \mathrm{a}$ & $150.8 \pm 5.2 \mathrm{abc}$ & $1.62 \mathrm{E}-06 \pm 6.94 \mathrm{E}-08 \mathrm{abc}$ \\
\hline & Dade & 2 & FL & $92.1 \pm 0.4$ & $159.7 \pm 14.0$ & $1.60 \mathrm{E}-06 \pm 1.15 \mathrm{E}-07$ \\
\hline & Donnie & 3 & FL & $103.7 \pm 1.5 \mathrm{a}$ & $164.2 \pm 8.2 \mathrm{a}$ & $2.10 \mathrm{E}-06 \pm 2.52 \mathrm{E}-07 \mathrm{a}$ \\
\hline & Pollock & 1 & FL & $102.5 \pm \mathrm{NA}$ & $146.0 \pm \mathrm{NA}$ & $1.77 \mathrm{E}-06 \pm \mathrm{NA}$ \\
\hline & Simmonds & 3 & FL & $103.8 \pm 4.8 \mathrm{a}$ & $153.2 \pm 6.8 \mathrm{ab}$ & $1.95 \mathrm{E}-06 \pm 2.25 \mathrm{E}-07 \mathrm{ab}$ \\
\hline & Waldin & 3 & FL & $88.4 \pm 5.3 \mathrm{bc}$ & $132.7 \pm 7.7 \mathrm{cde}$ & $1.38 \mathrm{E}-06 \pm 3.14 \mathrm{E}-07 \mathrm{bcd}$ \\
\hline
\end{tabular}

${ }^{\mathrm{x}}$ Variables are $D$, equivalent circle diameter (diameter of the circle having the same area as the measured vessel in $\mu \mathrm{m}) ; D_{\mathrm{MAX}}$, maximum vessel diameter (diameter of the circle having the same area as the measured vessel in $\mu \mathrm{m})$; Ks, xylem-specific potential hydraulic conductivity $\left(\mathrm{kg} \mathrm{m}^{-2} \mathrm{MPa}^{-1} \mathrm{~s}^{-1}\right)$

${ }^{y}$ Means containing the same letter within a column are not significantly different according to Fisher's LSD multiple comparisons test with a Benjamini and Hochberg $p$ value adjustment $(\alpha=0.05)$. Only cultivars with three or more samples were included in the analysis

${ }^{\mathrm{z}}$ Means that are not followed by a letter were not included in the analysis due to small sample sizes 
Table 4 Summary of vessel density and vessel aggregation characteristics of Persea americana cultivars

Variable $(\text { Mean } \pm \mathrm{SE})^{\mathrm{w}, \mathrm{x}, \mathrm{y}}$

\begin{tabular}{llllllll}
\hline Race & Cultivar & $n$ & Source & $V_{\mathrm{D}}^{\mathrm{z}}$ & $V_{\mathrm{G}}$ & $V_{S}$ & $V_{\mathrm{M}}$ \\
\hline Guatemalan & Nabal & 3 & FL \& CA & $20.5 \pm 4.5 \mathrm{a}$ & $1.36 \pm 0.12 \mathrm{abc}$ & $53.45 \pm 9.75 \mathrm{abc}$ & $2.19 \pm 0.06 \mathrm{a}$ \\
& R14T01 & 3 & FL & $24.5 \pm 1.1 \mathrm{a}$ & $1.29 \pm 0.04 \mathrm{bc}$ & $58.64 \pm 3.58 \mathrm{ab}$ & $2.15 \pm 0.07 \mathrm{a}$ \\
& R14T06 & 2 & FL & $23.6 \pm 1.8$ & $1.37 \pm 0.05$ & $52.04 \pm 3.55$ & $2.22 \pm 0.03$ \\
Mexican & Bacon & 3 & FL & $18.8 \pm 1.1 \mathrm{a}$ & $1.43 \pm 0.03 \mathrm{abc}$ & $45.88 \pm 2.76 \mathrm{bcd}$ & $2.20 \pm 0.01 \mathrm{a}$ \\
& Duke & 3 & CA & $20.0 \pm 2.7 \mathrm{a}$ & $1.21 \pm 0.02 \mathrm{c}$ & $68.05 \pm 2.04 \mathrm{a}$ & $2.09 \pm 0.02 \mathrm{a}$ \\
& Egas & 1 & FL & $21.2 \pm \mathrm{NA}$ & $1.34 \pm \mathrm{NA}$ & $52.27 \pm \mathrm{NA}$ & $2.15 \pm \mathrm{NA}$ \\
& LaPiscina & 1 & FL & $19.3 \pm \mathrm{NA}$ & $1.39 \pm \mathrm{NA}$ & $48.47 \pm \mathrm{NA}$ & $2.16 \pm \mathrm{NA}$ \\
& Romain & 2 & FL & $30.2 \pm 0.4$ & $1.73 \pm 0.13$ & $29.72 \pm 7.29$ & $33.77 \pm 2.51 \mathrm{~d}$ \\
& Catalina & 3 & FL & $21.6 \pm 0.3 \mathrm{a}$ & $1.60 \pm 0.06 \mathrm{a}$ & $2.49 \pm 0.01$ \\
& Dade & 2 & FL & $25.1 \pm 0.8$ & $1.47 \pm 0.07$ & $45.34 \pm 6.63$ & $2.32 \pm 0.02$ \\
& Donnie & 3 & FL & $26.6 \pm 2.4 \mathrm{a}$ & $1.39 \pm 0.04 \mathrm{abc}$ & $50.56 \pm 3.42 \mathrm{abcd}$ & $2.27 \pm 0.04 \mathrm{a}$ \\
& Pollock & 1 & FL & $22.8 \pm \mathrm{NA}$ & $1.50 \pm \mathrm{NA}$ & $41.12 \pm \mathrm{NA}$ & $2.30 \pm \mathrm{NA}$ \\
& Simmonds & 3 & FL & $25.1 \pm 2.1 \mathrm{a}$ & $1.45 \pm 0.09 \mathrm{abc}$ & $46.72 \pm 5.72 \mathrm{bcd}$ & $2.31 \pm 0.12 \mathrm{a}$ \\
& Waldin & 3 & FL & $27.0 \pm 2.2 \mathrm{a}$ & $1.50 \pm 0.04 \mathrm{ab}$ & $39.97 \pm 2.00 \mathrm{~cd}$ & $2.20 \pm 0.06 \mathrm{a}$ \\
\hline
\end{tabular}

${ }^{\mathrm{w}}$ Variables are $V_{D}$, vessel density (number of vessels per $\mathrm{mm}^{2}$ ); $V_{\mathrm{G}}$, vessel grouping index (mean number of vessels per group, solitary vessels are also considered a group); $V_{S}$, vessel solitary fraction (ratio of solitary vessels to all vessels); $V_{\mathrm{M}}$, mean group size of nonsolitary vessels

${ }^{\mathrm{x}}$ Except for the variable $V_{\mathrm{D}}$, means containing the same letter within a column are not significantly different according to Fisher's LSD multiple comparisons test with a Benjamini and Hochberg $p$ value adjustment $(\alpha=0.05)$. Only cultivars with three or more samples were included in the analysis

${ }^{\mathrm{y}}$ Means that are not followed by a letter were not included in the analysis due to small sample sizes

${ }^{\mathrm{z}} V_{\mathrm{D}}$ was analyzed using nonparametric analysis due to violations of the assumptions of ANOVA. Groups with the same letter in the same column were not statistically significant according to Dunn's multiple comparison with a Benjamini and Hochberg $p$ value adjustment $(\alpha=0.05)$. Only cultivars with three or more samples were included in analysis

analyzed using one-way ANOVA $(\alpha=0.05)$. Post hoc comparisons were made using Fisher's LSD test with a Benjamini and Hochberg (1995) $p$ value adjustment $(\alpha=0.05)$. Nonnormal data were analyzed using the Kruskal-Wallis test, followed by Dunn's multiple comparison test with a Benjamini and Hochberg (1995) $p$ value adjustment. For $D$ and $\mathrm{Ks}$, a grand mean was calculated for each tree from the mean of each of the four sections examined. For all remaining xylem characteristics, the mean for each tree was calculated from all four sections together. Means for each race and cultivar were calculated with tree means. The mean for $D$ based on individual vessels was also determined and is presented in Supplementary Table 1.

\section{Results}

\section{Vessel diameter}

There were significant differences in mean vessel diameter (D) between cultivars of the West Indian race $(98.6 \mu \mathrm{m})$ and the Mexican and Guatemalan races $(84.2$ and $82.5 \mu \mathrm{m}$, respectively) (Table 2, Fig. 1). Likewise, the West Indian race had a mean maximum vessel diameter $\left(D_{\mathrm{MAX}}=151.2 \mu \mathrm{m}\right)$ significantly larger than either the Guatemalan race $\left(D_{\mathrm{MAX}}=132.0 \mu \mathrm{m}\right)$ or the Mexican race $\left(D_{\mathrm{MAX}}=\right.$ $131.5 \mu \mathrm{m}$ ) (Table 2). Although individual cultivars of the Mexican and Guatemalan races generally had smaller mean vessel diameters $(D)$ and mean maximum vessel diameters $\left(D_{\mathrm{MAX}}\right)$ than cultivars of the West Indian race (Table 3 ), small sample sizes for some cultivars limited the ability to detect significant differences. Whereas Guatemalan cultivars were fairly consistent for mean vessel diameter $(D)$, there was considerable variation among those of the Mexican race (Table 3 ). The grand mean and the mean based on individual vessels for $D$ were very similar (Table 1 and Supplementary Table 1).

\section{Vessel aggregation}

No significant differences were found among the races in vessel aggregation and vessel density $\left(V_{\mathrm{D}}\right)$. There were also no significant differences among any of the individual cultivars for mean vessel density or mean group size of nonsolitary vessels $\left(V_{\mathrm{M}}\right)$. However, there were statistical differences between some of the cultivars for mean vessel grouping index $\left(V_{\mathrm{G}}\right)$ and mean vessel solitary fraction $\left(V_{S}\right)$, which is the ratio of solitary vessels to all vessels (Table 4 ). 
Fig. 1 Transverse sections of avocado stem tissue stained with safranin $\mathrm{O}$ from which vessel diameter was measured for three different races. The Guatemalan races ("Nabal," top) and the Mexican races ("Duke," middle) had significantly smaller vessels than the West Indian races ("Simmonds," bottom). Bar = $1500 \mu \mathrm{m}$

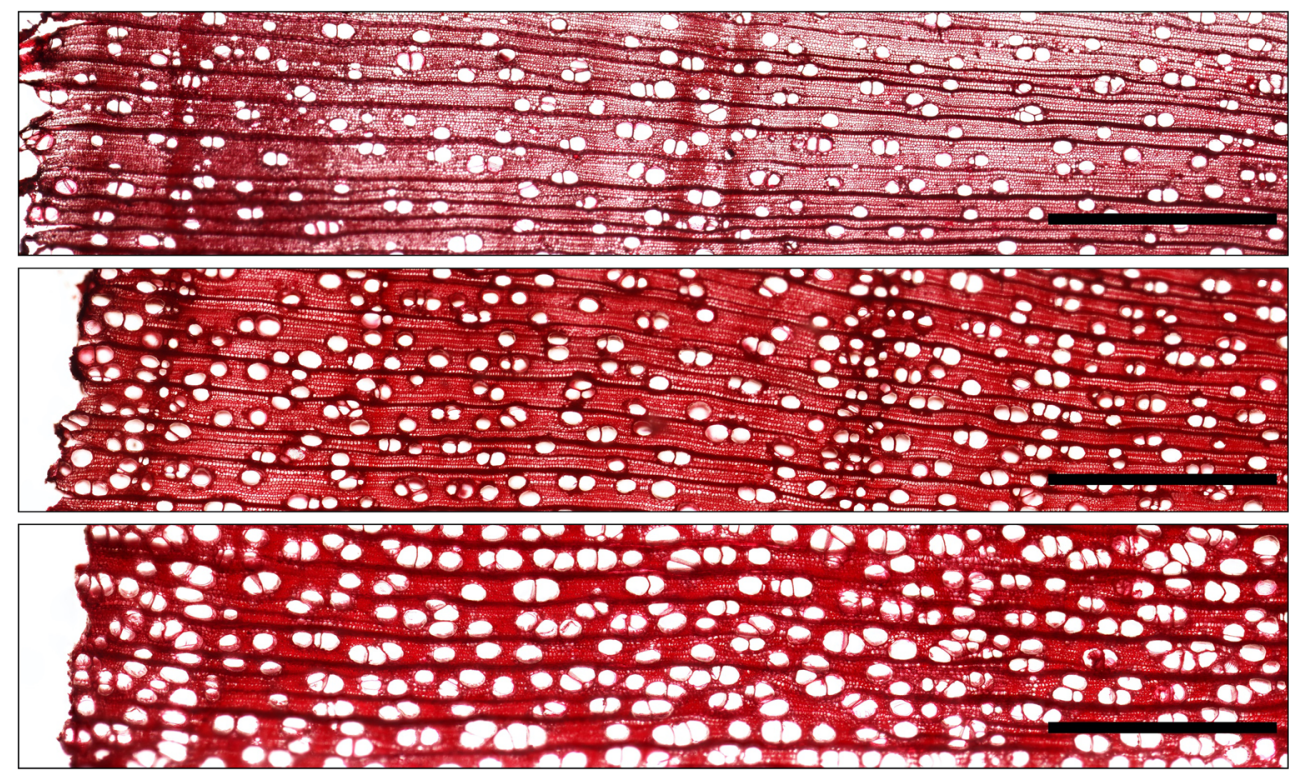

\section{Xylem-specific potential hydraulic conductivity}

The West Indian race had a significantly larger mean xylemspecific potential hydraulic conductivity (Ks) than the other two races $(p<0.05)$, but differences between the Mexican and Guatemalan races were not significant ( $p>0.05$, Table 2). For individual cultivars, the Mexican and Guatemalan cultivars generally had smaller means than that of the West Indian cultivars (Table 3 ). For cultivars that had three replicates, "Bacon" (Mexican) had the smallest mean Ks (6.67E$07 \mathrm{~kg} \mathrm{~m}^{-2} \mathrm{MPa}^{-1} \mathrm{~s}^{-1}$ ), while "Donnie" (West Indian) had the largest (2.10E-06 $\mathrm{kg} \mathrm{m}^{-2} \mathrm{MPa}^{-1} \mathrm{~s}^{-1}$ ) (Table 3).

\section{Discussion}

In a previous study, Ploetz et al. (2015) hypothesized that the races of avocado with different xylem attributes would impact hydraulic conductivity. In the present study, mean xylem diameters and mean maximum xylem diameters were 17 and $15 \%$ greater in the West Indian race than either the Mexican or Guatemalan races (Table 2). These results agree with those of Reyes-Santamaría et al. (2002), who also found that the West Indian race had larger vessel diameters than the Guatemalan and Mexican races; however, in their study, the differences were considerably smaller. Previously, Campbell et al. (2016) reported that lumen cross-sectional areas of the laurel wilttolerant camphortree were significantly smaller than avocado and swamp bay, which are susceptible to laurel wilt. Thus, among the lauraceous hosts that have been examined, but especially in avocado, there appears to be a correlation of increased susceptibility with greater lumen dimensions (Reyes-Santamaría et al. 2002; Ploetz et al. 2012, 2015; Campbell et al. 2016; results from the present study). One notable exception to this in avocado appears to be the cultivar "Hass," which has relatively large vessels (Reyes-Santamaría et al. 2002) and relatively low susceptibility to laurel wilt (Ploetz et al. 2012).

Relationships between disease resistance and vessel size have been examined in other pathosystems, most notably Dutch elm disease. Multiple studies indicate that resistant species and genotypes of elm generally have smaller vessel diameters than those that are susceptible (Elgersma 1970; McNabb Jr et al., 1970; Sinclair et al. 1975; Solla and Gil 2002). Sinclair et al. (1975) had proposed many years ago that the use of vessel diameter as a preliminary screening method for resistance to Dutch elm disease in American elm (Ulmus americana L.) should be investigated. Another woody plant that has been examined for the relationship between xylem characteristics and disease resistance is Vitis (Pouzoulet et al. 2014, 2017). When examining three cultivars with varying levels of susceptibility to fungal vascular diseases, Pouzoulet et al. (2014) found that the most susceptible cultivar had the greatest mean vessel diameter and the least susceptible cultivar had the smallest mean vessel diameter.

The ability of host plants to contain vascular pathogens is a critical determinant in their ability to resist these diseases. Xylem attributes that slow pathogen spread and rapidly block vessels with tyloses should enhance disease resistance (Pouzoulet et al. 2019). Narrow vessels could be more easily sealed to contain a pathogen, whereas shorter vessels would present the pathogen with more obstacles to movement, such as xylem plates and pit membranes (Pouzoulet et al. 2014). While xylem characteristics may contribute to increased disease resistance in different genotypes of avocado, host response in addition to vessel characteristics may also play a role. Previous studies in elm have shown that compartmentalization can play an important role in resistance to Dutch elm 
disease (Buisman 1935; Banfield 1968; Shigo and Tippett, 1981; Rioux and Ouellette 1991; Et-Touil et al. 2005; Beier et al. 2017; Beier and Blanchette 2018). Compartmentalization has also been demonstrated in oak trees inoculated with Bretziella fagacearum (Bretz) Z.W. de Beer, Marinc., T.A. Duong \& M.J. Wingf. (syn. Ceratocystis fagacearum), which causes oak wilt (Jacobi and MacDonald 1980; Tainter and Fraedrich 1986).

Differences in susceptibility to laurel wilt in avocado may be due to a number of different resistance mechanisms. However, insights from the present study indicate that vessel diameter may be a key factor in susceptibility and resistance to this disease. Additional studies are needed to examine the susceptibility of the West Indian race and the specific xylem characteristics and host responses that limit infection by the pathogen, which could be associated with vessel attributes. Continued histological studies are also warranted to characterize compartmentalization mechanisms among the avocado races. The results presented here provide important basic information and a beginning to better understand this hostparasite interaction and its potential use for screening for resistant avocado which is desperately needed.

Acknowledgments We thank Eric Foecht for the samples from Irvine, CA, and Mike Winterstein for help identifying trees in the USDA-ARS collection in Miami, and Jason Smith at the University of Florida, Gainesville, for his suggestions and discussions.

Authors' contributions All authors contributed to the study conception and design. Material preparation, data collection, and analysis were performed by Garrett Beier, Benjamin Held, Connor Lund, and Robert Blanchette. Study materials and cultivar information were provided by Joshua Konkol and Randy Ploetz. The first draft of the manuscript was written by Garrett Beier and Robert Blanchette, and all authors commented on previous versions of the manuscript. All authors read and approved the manuscript.

Funding This work was supported, in part, by NIFA grants \#2015-09347 and \#2015-51181-24257 from the National Institute for Food and Agriculture and USDA Hatch Project MIN-22-081.

\section{Compliance with ethical standards}

Conflict of interest The authors declare that they have no conflict of interest.

Open Access This article is licensed under a Creative Commons Attribution 4.0 International License, which permits use, sharing, adaptation, distribution and reproduction in any medium or format, as long as you give appropriate credit to the original author(s) and the source, provide a link to the Creative Commons licence, and indicate if changes were made. The images or other third party material in this article are included in the article's Creative Commons licence, unless indicated otherwise in a credit line to the material. If material is not included in the article's Creative Commons licence and your intended use is not permitted by statutory regulation or exceeds the permitted use, you will need to obtain permission directly from the copyright holder. To view a copy of this licence, visit http://creativecommons.org/licenses/by/4.0/.

\section{References}

Ashworth VETM, Clegg MT (2003) Microsatellite markers in avocado (Persea americana mill.): genealogical relationships among cultivated avocado genotypes. Journal of Heredity 94:407-415

Banfield WM (1968) Dutch elm disease recurrence and recovery in American elm. Journal of Phytopathology 62:21-60

Beier GL, Blanchette RA (2018) Defense responses in the xylem of Ulmus americana cultivars after inoculation with Ophiostoma novo-ulmi. Forest Pathology 48:e12453

Beier GL, Held BW, Giblin CP, Cavender-Bares J, Blanchette RA (2017) American elm cultivars: variation in compartmentalization of infection by Ophiostoma novo-ulmi and its effects on hydraulic conductivity. Forest Pathology 47:e12369

Benjamini Y, Hochberg Y (1995) Controlling the false discovery rate: a practical and powerful approach to multiple testing. Journal of the Royal Statistical Society Series B Methodology 57:289-300

Boza EJ, Tondo CL, Ledesma N, Campbell RJ, Bost J, Schnell RJ, Gutiérrez OA (2018) Genetic differentiation, races and interracial admixture in avocado (Persea americana mill.), and Persea spp. evaluated using SSR markers. Genetic Resources and Crop Evolution 65:1195-1215

Buisman C (1935) The anatomy of wood of elms infected with Graphium ulmi. Plantenzickten 41:04-120

Campbell AS, Ploetz RC, Rollins JA (2016) Comparing avocado, swamp bay, and camphortree as hosts of Raffaelea lauricola using a green fluorescent protein (GFP)-labeled strain of the pathogen. Phytopathology 107:70-74

Carlquist S (2001) Comparative wood anatomy - systematic, ecological, and evolutionary aspects of Dicotyledon wood, 2nd edn. Berlin, Springer Verlag, $448 \mathrm{pp}$

Chanderbali AS, Soltis DE, Soltis PS, Wolstenholme BN (2013) Taxonomy and botany. In: Scaffer B, Wolstenholm BN, Whiley AW (eds) The avocado: botany. Production and Uses. CAB International, Wallingford, pp 31-50

Chen H, Morrell PL, Ashworth VETM, Cruz MDL, Clegg MT (2009) Tracing the geographic origins of major avocado cultivars. Journal Heredity 100:56-65

Economic Research Service (2019) Avocado. United States Department of Agriculture. https://data.ers.usda.gov/reports.aspx? programArea $=$ fruit\&stat_year $=2009 \&$ top $=5 \&$ HardCopy $=$ True \& R o w s P e r P a g e $=25 \& \mathrm{~g} \mathrm{r}$ o u p N a m e $=$ Noncitrus \& commodity Name $=$ Avocados $\& I D=17851 \#$ Pbdf876ded8d5491797cbeb11139dbd20_2_110 ()

Elgersma DM (1970) Length and diameter of xylem vessels as factors in resistance of elms to Ceratocystis ulmi. Netherlands Journal of Plant Pathology 76:79-182

Et-Touil A, Rioux D, Mathieu FM, Bernier L (2005) External symptoms and histopathological changes following inoculation of elms putatively resistant to Dutch elm disease with genetically close strains of Ophiostoma. Canadian Journal of Botany 83:656-667

Fraedrich SW, Harrington TC, Rabaglia RJ, Ulyshen MD, Mayfield AE III, Hanula JL, Eickwort JM, Miller DR (2008) A fungal symbiont of the redbay ambrosia beetle causes a lethal wilt in redbay and other Lauraceae in the southeastern United States. Plant Disease 92:215224

Harrington TC, Fraedrich SW, Aghayeva D (2008) Raffaelea lauricola, a new ambrosia beetle symbiont and pathogen on the Lauraceae. Mycotaxon 104:399-404

Jacobi WR, MacDonald WL (1980) Colonization of resistant and susceptible oaks by Ceratocystis fagacearum. Phytopathology 70:618-623

Kuhn DN, Groh A, Rahaman J, Freeman B, Arpaia ML, Van den Berg N, Abeysekara N, Manosalva P, Chambers AH (2019) Creation of an avocado unambiguous genotype SNP database for germplasm 
curation and as an aid to breeders. Tree Genetics and Genomes 15: 71

McNabb HS Jr, Heybroek HM, Macdonald WL (1970) Anatomical factors in resistance to Dutch elm disease. Netherlands Journal of Plant Pathology 76:196-204

National Agricultural Statistics Service (2018) Noncitrus fruits and nuts 2017 summary. United States Department of Agriculture. https:// www.nass.usda.gov/Publications/Todays_Reports/reports/ ncit0618.pdf ()

Nonweiler TRF (1975) Flow of biological fluids through non-ideal capillaries. In: Zimmerman MH, Milburn JA (eds) Encyclopedia of plant physiology, new series, Transport in plants I, phloem transport, vol 1. Appendix I. Springer, Berlin, pp 474-477

Ploetz RC, Pérez-Martínez JM, Smith JA, Hughes M, Dreaden TJ, Inch SA, Fu Y (2012) Responses of avocado to laurel wilt, caused by Raffaelea lauricola. Plant Pathology 61:801-808

Ploetz RC, Schaffer B, Vargas AI, Konkol JL, Salvatierra J, Wideman R (2015) Impact of laurel wilt, caused by Raffaelea lauricola, on leaf gas exchange and xylem sap flow in avocado, Persea americana. Phytopathology 105:433-440

Ploetz RC, Kendra PE Choudhury RA, Rollins J, Campbell A, Garrett K, Hughes M, Dreaden,T (2017). Laurel wilt in native and agricultural ecosystems: understanding the drivers and scales of complex pathosystems. Forests 8:48

Pouzoulet J, Pivovaroff A, Santiago L, Rolshausen PE (2014) Can vessel dimension explain tolerance toward fungal vascular wilt diseases in woody plants? Lessons from Dutch elm disease and esca disease in grapevine. Frontiers in Plant Science 5:253

Pouzoulet J, Scudiero E, Schiavon M, Rolshausen PE (2017) Xylem vessel diameter affects the compartmentalization of the vascular pathogen Phaeomoniella chlamydospora in grapevine. Frontiers in Plant Science 8:1442
Pouzoulet J, Scudiero E, Schiavon M, Santiago LS, Rolshausen PE (2019) Modeling of xylem vessel occlusion in grapevine. Tree Physiology 39:1438-1445

Reyes-Santamaría I, Terrazas T, Barrientos-Priego AF, Trejo C (2002) Xylem conductivity and vulnerability in cultivars and races of avocado. Scientia Horticulturae 92:97-105

Rioux D, Ouellette GB (1991) Barrier zone formation in host and nonhost trees inoculated with Ophiostoma ulmi. I. Anatomy and histochemistry. Canadian Journal of Botany 69:2055-2073

Schneider CA, Rasband WS, Eliceiri KW (2012) NIH Image to ImageJ: 25 years to image analysis. Nature Methods 9:671-675

Schnell RJ, Brown JS, Olano CT, Power EJ, Krol CA, Kuhn DN, Motamayor JC (2003) Evaluation of avocado germplasm using microsatellite markers. Journal of the American Society of Horticulture Science 128:881-889

Shigo AL, Tippett JT (1981) Compartmentalization of American elm tissues infected by Ceratocystis ulmi. Plant Disease 65:715-718

Sinclair WA, Zahand JP, Melching JB (1975) Anatomical marker for resistance of Ulmus americana to Ceratocystis ulmi. Phytopathology 65:349-352

Solla A, Gil L (2002) Xylem vessel diameter as a factor in resistance of Ulmus minor to Ophiostoma novo-ulmi. Forest Pathology 32:123134

Tainter FH, Fraedrich SW (1986) Compartmentalization of Ceratocystis fagacearum in Turkey oak in South Carolina. Phytopathology 76: 698-701

von Arx G, Kueffe C, Fonti P (2013) Quantifying plasticity in vessel grouping - added value from the image analysis tool ROXAS. International Association of Wood Anatomist Journal 34:433-445

Publisher's note Springer Nature remains neutral with regard to jurisdictional claims in published maps and institutional affiliations. 